\title{
Genomic Profiling and Clinicopathological Characteristics of Neuroendocrine Tumors of the Lung in East Asian Patients
}

\author{
MOONSIK KIM, YEON SEUNG CHUNG, KYOUNG A KIM and HYO SUP SHIM
}

Department of Pathology, Severance Hospital, Yonsei University College of Medicine, Seoul, Republic of Korea

\begin{abstract}
Background/Aim: In recent years, the genomic landscape of neuroendocrine tumors (NETS) of the lung has been investigated. However, more data are necessary to elucidate the heterogeneous nature of NETs, especially in East Asian patients. Patients and Methods: A total of 64 patients who underwent surgical resection for lung NETs [26 typical or atypical carcinoid tumors, 21 large-cell neuroendocrine carcinomas (LCNECS), and 19 small-cell lung carcinomas (SCLCS)] were enrolled, and samples from 46 patients were subjected to targeted next-generation sequencing. Results: Co-mutations of tumor protein p53 (TP53) and RB transcriptional corepressor 1 (RB1) were detected in 15\%, 42\%, and 93\% of carcinoid tumors, LCNECs, and SCLCs, respectively. Oncogenic or targetable genetic alterations identified in this study included mutations of KRAS proto-oncogene (KRAS), phosphatidylinositol-4,5bisphosphate 3-kinase catalytic subunit alpha (PIK3CA), ALK receptor tyrosine kinase (ALK), mitogen-activated protein kinase kinase 1 (MAP2K1), and isocitrate dehydrogenase 1 (IDH1), as well as amplifications of erb-b2 receptor tyrosine kinase 2 (ERBB2), fibroblast growth factor receptor 1 (FGFR1), CD274 molecule (CD274), and MYCN proto-oncogene (MYCN). These alterations were more frequently found in high-grade NETs than in carcinoid tumors (33.3\% vs. 7.7\%). Programmed cell death-ligand 1 expression was strongly associated with the LCNEC subtype among NETs ( $p=0.002)$. Conclusion: The mutational status of TP53 and RB1 was significantly associated with NET subtypes in East Asian patients. Targeted therapy or
\end{abstract}

This article is freely accessible online.

Correspondence to: Hyo Sup Shim, MD, Ph.D., Department of Pathology, Severance Hospital, Yonsei University College of Medicine, 50 Yonsei-ro, Seodaemun-gu, Seoul 03722, Republic of Korea. Tel: +82 222281762, Fax: +82 222277939, e-mail: shimhs@yuhs.ac

Key Words: Neuroendocrine tumor, lung, TP53, RB1, next-generation sequencing, PD-L1. immunotherapy may serve as a treatment option in a subset of patients with high-grade NETs.

Neuroendocrine tumors (NETs) of the lung are currently categorized based on their histological features. According to the 2015 World Health Organization (WHO) Classification of Lung Tumors and the International Agency for Research on Cancer (IARC) and WHO expert consensus proposal for neuroendocrine neoplasms $(1,2)$, lung NETs can be categorized into low-grade [typical carcinoid tumors (TCs)], intermediategrade [atypical carcinoid tumors (ACs)], and high-grade [largecell neuroendocrine carcinomas (LCNECs) and small-cell lung carcinomas (SCLCs)] tumors. They are characterized by histological features of neuroendocrine morphology (organoid nesting, palisading, or rosette-like structures) and express immunohistochemical neuroendocrine markers. TCs usually present with a centrally located mass involving the bronchi. Microscopically, they comprise monotonous cells with a granular cytoplasm that forms characteristic nest, ribbon, or festoon patterns. The morphology of ACs is similar to that of TCs; however, they also demonstrate increased mitotic activity (2-10 mitoses per $2 \mathrm{~mm}^{2}$ ) with/without the presence of necrosis. Of the high-grade NETs, LCNEC is a type of nonsmall-cell lung carcinoma (NSCLC) that displays abundant cytoplasm and prominent nucleoli with neuroendocrine differentiation. SCLC consists of small cells with scant cytoplasm, a fine granular chromatin pattern, and inconspicuous nucleoli. High-grade NETs typically show high mitotic activity (>10 mitoses per $2 \mathrm{~mm}^{2}$ ) and an increased Ki-67 cell proliferation labeling index (>40\%) (3).

In recent years, comprehensive genomic profiling of lung NETs has been reported (4-10). In addition to morphological classification, recent studies have suggested that NETs consist of heterogeneous tumors despite sharing a similar morphology $(4,5,7,8,11-16)$. They can be further subdivided into molecular subtypes based on genomic characteristics $(4,5,7,8,11,15,16)$.

However, most of the existing research on lung NETs has focused on Western populations. Multiple studies have demonstrated that ethnicity plays a role in the prevalence of important genetic markers in NSCLC (17). Therefore, it is 
worthwhile investigating the genomic profiling of lung NETs in Asian populations. In addition to the genetic analyses of lung NETs, recent studies have also suggested that high-grade neuroendocrine carcinomas may be associated with a distinct tumor immune microenvironment compared to carcinoid tumors (18-22). In this study, we investigated the genetic profiling, clinicopathologic features, and programmed cell death-ligand 1 (PD-L1) status of lung NETs in East Asian patients.

\section{Patients and Methods}

Patients. Patients who underwent surgical resection for NETs of the lung (including TCs, ACs, LCNECs, and SCLCs) between 2005 and 2012 were enrolled in this study. All cases were chemo-naïve. Detailed clinical data, including age, sex, smoking history, stage, and survival, were retrieved from medical records. Tumor stage was determined according to the eighth edition of the American Joint Committee on Cancer (AJCC) staging manual (23). The Institutional Review Board approved this study (No. 4-2017-0206). Written informed consent from the patients was waived due to the retrospective nature of the study.

Pathological evaluation. Two pathologists (MK and HSS) who specialize in lung pathology reviewed all of the available hematoxylin and eosin-stained or immunohistochemically stained slides. All diagnoses were made according to the 2015 WHO classification of lung tumors (1). Discrepancies in classification were resolved by consensus discussion. Pathological findings, including mitoses, necrosis, and invasion to lymphovascular spaces or pleura, were recorded.

Immunohistochemistry (IHC) and interpretation. A representative tumor section was stained with antibodies against cytokeratin AE1/AE3 (mouse monoclonal, clone AE1/AE3, 1:600; Agilent, Santa Clara, CA, USA), synaptophysin (mouse monoclonal, clone DAKSYNAP, 1:900; Agilent), chromogranin A (mouse monoclonal, clone DAK-A3, 1:500; Agilent), CD56 (mouse monoclonal, clone CD564, 1:100; Novocastra, Newcastle, UK), human epidermal growth factor receptor 2 (PATHWAY anti-HER-2/neu (4B5) Rabbit Monoclonal Primary Antibody; Ventana Medical Systems, Tucson, AZ, USA), and Ki-67 (mouse monoclonal, clone MB-1, 1:150; Agilent) using the Ventana BenchMark XT Automated Staining System (Ventana Medical Systems). Positive and negative controls were developed for the assessment of staining quality. For PD-L1 22C3 IHC, the sections were stained using an Autostainer Link 48 platform (Agilent) following the manufacturer's instructions. The tumor proportion score (TPS) was determined as the percentage of tumor cells showing membranous positivity to PD-L1 antibody regardless of the staining intensity. A TPS $\geq 1 \%$ was defined as PD-L1 positivity.

Targeted DNA and RNA next-generation sequencing (NGS). Targeted DNA and RNA sequencing were performed using a customized cancer panel (NGeneBio, Seoul, Republic of Korea). The customized cancer panel was designed to detect 46 cancer-related genes, including 46 genes with potential single nucleotide variants (SNVs) and insertions and deletions (indels), 20 genes with potential amplification, and 17 genes with potential fusion variants (Table I). Briefly, representative sections containing at least $30 \%$ tumor volume were selected. Formalin-fixed, paraffin-embedded (FFPE) tissue-derived DNA and RNA were extracted using QIAGEN AllPrep DNA/RNA FFPE Kit
Table I. Genes targeted in the next-generation sequencing panel.

\begin{tabular}{|c|c|c|c|c|}
\hline Gene & $\begin{array}{l}\text { Encoded } \\
\text { protein }\end{array}$ & $\begin{array}{l}\text { SNVs \& indel } \\
\text { (DNA) }\end{array}$ & $\begin{array}{l}\text { Amplification } \\
\text { (DNA) }\end{array}$ & $\begin{array}{l}\text { Fusion } \\
\text { (RNA) }\end{array}$ \\
\hline AKT1 & AKT1 & $\mathrm{x}$ & $\mathrm{x}$ & $\mathrm{x}$ \\
\hline ALK & ALK & $x$ & $x$ & \\
\hline ARAF & ARAF & $x$ & & \\
\hline BRAF & BRAF & $x$ & $x$ & $x$ \\
\hline BRCA1 & BRCA1 & $x$ & & \\
\hline BRCA2 & BRCA2 & $x$ & & \\
\hline CD274 & PD-L1 & $x$ & $x$ & \\
\hline CRKL & CRKL & $x$ & $x$ & \\
\hline DDR2 & DDR2 & $x$ & & \\
\hline EGFR & EGFR & $x$ & $x$ & $x$ \\
\hline ERBB2 & HER2 & $x$ & $x$ & $x$ \\
\hline ERBB4 & ERBB4 & $x$ & & $x$ \\
\hline EZH2 & EZH2 & $x$ & & \\
\hline FGFR 1 & FGFR1 & $x$ & $x$ & $x$ \\
\hline FGFR2 & FGFR2 & $x$ & $x$ & $x$ \\
\hline FGFR3 & FGFR3 & $x$ & $x$ & $x$ \\
\hline IDH1 & IDH1 & $x$ & & \\
\hline IDH2 & IDH2 & $x$ & & \\
\hline JAK1 & JAK1 & $x$ & & \\
\hline JAK2 & JAK2 & $x$ & & \\
\hline JAK3 & JAK3 & $x$ & & \\
\hline KIT & KIT & $x$ & $x$ & \\
\hline KRAS & KRAS & $x$ & $x$ & \\
\hline MAP2K1 & MAP2K1 & $x$ & & \\
\hline MET & HGFR & $x$ & $x$ & $x$ \\
\hline MTOR & mTOR & $x$ & & \\
\hline MYC & MYC & $x$ & $x$ & $x$ \\
\hline MYCN & $\mathrm{N}$-myc & $x$ & $x$ & \\
\hline NRAS & NRAS & $x$ & & \\
\hline NRG1 & NRG1 & $x$ & & $x$ \\
\hline NTRK1 & TrkA & $x$ & & $x$ \\
\hline NTRK2 & TrkB & $x$ & & $x$ \\
\hline NTRK3 & TrkC & $x$ & & $x$ \\
\hline PDGFRA & PDGFRA & $x$ & $x$ & $x$ \\
\hline PIK3CA & PIK3CA & $x$ & $x$ & \\
\hline PTEN & PTEN & $x$ & & \\
\hline $\mathrm{RB} 1$ & $\mathrm{Rb}$ & $x$ & & \\
\hline RET & RET & $x$ & $x$ & $x$ \\
\hline RICTOR & RICTOR & $x$ & $x$ & \\
\hline RIT1 & RIT1 & $\times$ & & \\
\hline ROS1 & ROS1 & $x$ & $x$ & $x$ \\
\hline SMARCA4 & BRG1 & $x$ & & \\
\hline STK11 & STK11 & $x$ & & \\
\hline TP53 & p53 & $x$ & & \\
\hline $\mathrm{TSC} 1$ & TSC1 & $x$ & & \\
\hline TSC2 & TSC2 & $x$ & & \\
\hline
\end{tabular}

SNV: Single nucleotide variant; indel: insertion and deletion.

(Qiagen, Hilden, Germany). After hybridization capture-based target enrichment using $100 \mathrm{ng}$ of DNA and $500 \mathrm{ng}$ of RNA, paired-end sequencing $(2 \times 150 \mathrm{bp})$ was performed using a MiSeq sequencer (Illumina, San Diego, CA, USA) according to the manufacturer's instructions. SNVs, indels, and copy number variations were analyzed using the Burrows-Wheeler Aligner and Genome Analysis Tool Kit. Variants with a total depth of at least $100 \times$ and a variant allele 

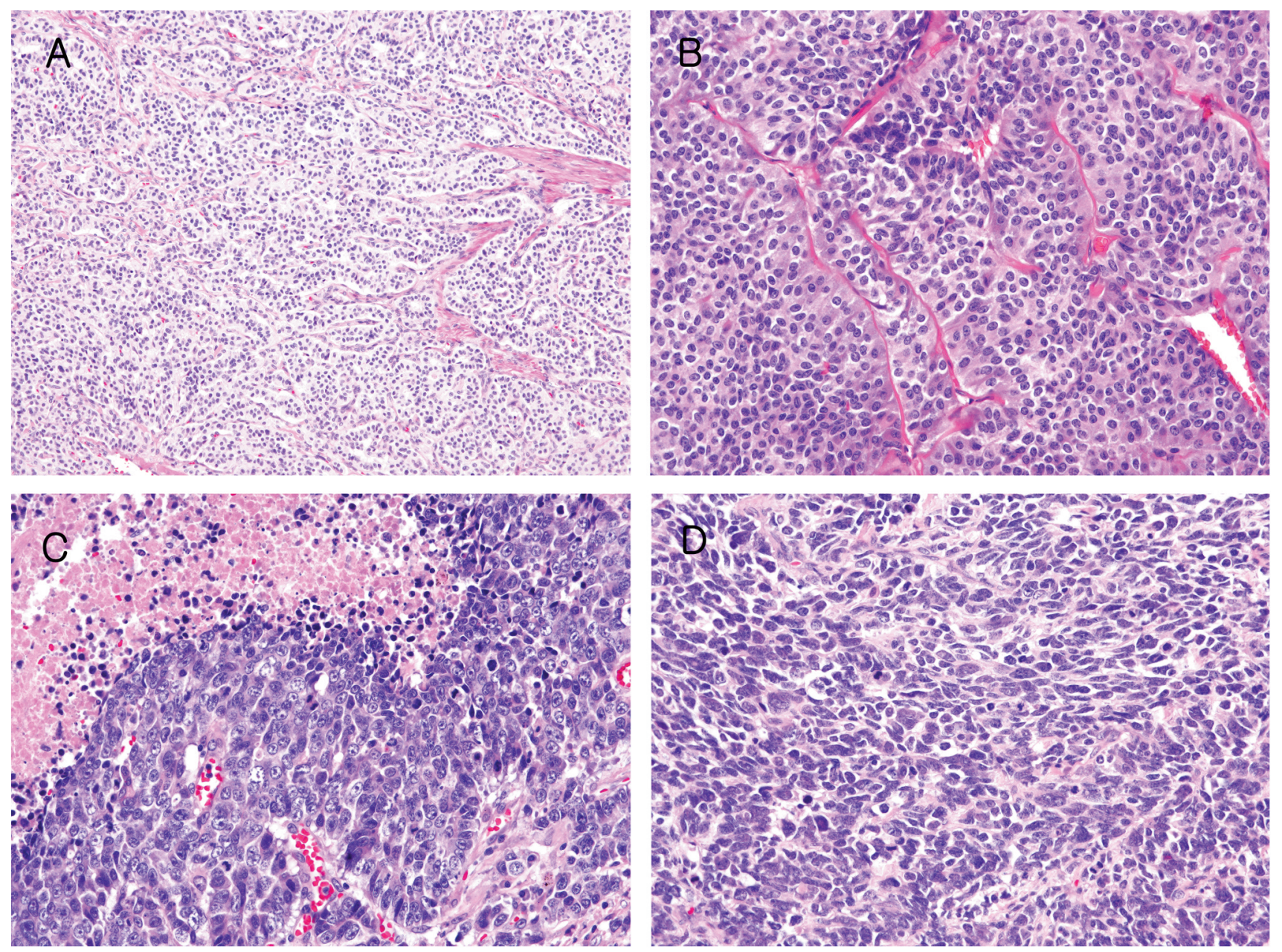

Figure 1. Representative photos of lung neuroendocrine tumors according to subtype. A: typical carcinoid tumor, B: atypical carcinoid tumor, C: large-cell neuroendocrine carcinoma, and D: small-cell lung carcinoma (original magnifications: A: ×100; B-D: ×200).

frequency of at least 3\% were included for analysis. Fusion variants were determined using STAR-Fusion and FusionCatcher. Variant interpretation was based on recommendations from the Association for Molecular Pathology, the American Society of Clinical Oncology, and the College of American Pathologists (24).

Statistical analysis. Chi-square tests were used to demonstrate the relationships between clinicopathological and categorical parameters. Recurrence-free (RFS) and overall (OS) survival were investigated using the Kaplan-Meier method. To determine statistical differences between survival times, the log-rank test was performed. A $p$-value of less than 0.05 was considered as statistically significant. All statistical calculations were conducted using IBM SPSS Statistics 23 software (IBM, Armonk, NY, USA).

\section{Results}

Clinicopathologic characteristics of NETs. A total of 64 patients who underwent complete surgical resection and were diagnosed with primary lung NETs were enrolled in this study.
Fifteen cases (23.4\%) were classified as TCs, nine (14.0\%), as ACs, 21 (32.9\%), as LCNECs, and 19 (29.7\%), as SCLCs (Figure 1). ClinicopathologicaI characteristics according to NET subtype are summarized in Table II. Of the 64 patients, 45 patients $(70.3 \%)$ were male, and $19(29.7 \%)$ were female. The mean age was 61.2 years, and the age ranged from 24 to 78 years. There were significant differences in age $(p<0.001)$, gender $(p=0.001)$, smoking history $(p<0.001)$, tumor size $(p=0.031)$, pleural invasion $(p=0.011)$, lymphovascular invasion $(p=0.001)$, lymph node metastasis $(p=0.003)$, and pathologic stages $(p=0.011)$ among the subtypes. In terms of survival, the median period of follow-up was 38 months at the time of analysis. Kaplan-Meier analyses for overall OS and RFS demonstrated significant differences according to NET subtype ( $p=0.005$ and $p=0.004$, respectively; Figure 2).

Overview of the genomic profiling of NETs. We then investigated the genomic profiling of a total of 46 NETs 
Table II. Patient characteristics according to the lung neuroendocrine tumor subtype.

\begin{tabular}{|c|c|c|c|c|c|c|}
\hline Variable & All (n=64) & $\mathrm{TC}(\mathrm{n}=15)$ & $\mathrm{AC}(\mathrm{n}=9)$ & LCNEC $(n=21)$ & $\operatorname{SCLC}(n=19)$ & $p$-Value \\
\hline Age (mean) & $61.2 \pm 11.2$ & $55.1 \pm 14.6$ & $51.9 \pm 10.9$ & $65.4 \pm 6.5$ & $65.8 \pm 7.5$ & $<0.001$ \\
\hline Gender & & & & & & 0.001 \\
\hline Male & $45(70.3 \%)$ & $7(46.7 \%)$ & $3(33.3 \%)$ & $18(85.7 \%)$ & $17(89.5 \%)$ & \\
\hline Female & $19(29.7 \%)$ & $8(53.3 \%)$ & $6(66.7 \%)$ & $3(14.3 \%)$ & $2(10.5 \%)$ & \\
\hline Smoking & & & & & & $<0.001$ \\
\hline Ever & $45(70.3 \%)$ & $7(46.7 \%)$ & $2(22.2 \%)$ & $19(90.5 \%)$ & $17(89.5 \%)$ & \\
\hline Never & $19(29.7 \%)$ & $8(53.3 \%)$ & $7(77.8 \%)$ & $2(9.5 \%)$ & $2(10.5 \%)$ & \\
\hline Tumor size & $2.7 \pm 1.5$ & $1.7 \pm 0.5$ & $2.6 \pm 1.7$ & $3.4 \pm 1.7$ & $2.7 \pm 1.6$ & 0.031 \\
\hline PL & & & & & & 0.011 \\
\hline Present & $12(18.7 \%)$ & $0(0.0 \%)$ & $0(0.0 \%)$ & $8(38.1 \%)$ & $4(21.1 \%)$ & \\
\hline Absent & $52(81.3 \%)$ & $15(100.0 \%)$ & $9(100.0 \%)$ & $13(61.9 \%)$ & $15(78.9 \%)$ & \\
\hline LVI & & & & & & 0.001 \\
\hline Present & $23(35.9 \%)$ & $1(6.7 \%)$ & $0(0.0 \%)$ & $10(47.6 \%)$ & $12(63.2 \%)$ & \\
\hline Absent & $41(64.1 \%)$ & $14(93.3 \%)$ & $9(100.0 \%)$ & $11(52.4 \%)$ & $7(36.8 \%)$ & \\
\hline LN metastasis & & & & & & 0.003 \\
\hline Present & $26(40.6 \%)$ & $4(26.7 \%)$ & $0(0.0 \%)$ & $9(42.9 \%)$ & $13(68.4 \%)$ & \\
\hline Absent & $38(59.4 \%)$ & $11(73.3 \%)$ & $9(100.0 \%)$ & $12(57.1 \%)$ & $6(31.6 \%)$ & \\
\hline TNM stage & & & & & & 0.011 \\
\hline Stage I & $31(48.4 \%)$ & $11(73.3 \%)$ & $8(88.9 \%)$ & $7(33.3 \%)$ & $5(26.3 \%)$ & \\
\hline Stage II & $17(26.6 \%)$ & $1(6.7 \%)$ & $1(11.1 \%)$ & $7(33.3 \%)$ & $8(42.1 \%)$ & \\
\hline Stage III & $16(25.0 \%)$ & $3(20.0 \%)$ & $0(0.0 \%)$ & $7(33.3 \%)$ & $6(31.6 \%)$ & \\
\hline
\end{tabular}

AC: Atypical carcinoid tumor; LCNEC: large-cell neuroendocrine carcinoma; LN: lymph node; LVI: lymphovascular invasion; PL: pleural invasion; SCLC: small-cell lung carcinoma; TC: typical carcinoid tumor.

(seven TCs, six ACs, 19 LCNECs, and 14 SCLCs) using targeted NGS. Cases were selected on the basis of archival FFPE tissue availability for NGS analysis. There were no differences in clinicopathological parameters between the whole cohort $(n=64)$ and the subset analyzed by NGS $(n=46)$. The mean depth was 390'. Genetic alterations according to NET subtype are summarized in Figure 3 and Table III. A total of 77 nonsynonymous mutations (four in TCs, four in ACs, 34 in LCNECs, and 35 in SCLCs) and five copy number gains (four in LCNECs and one in SCLCs) were identified. RNA fusions were not detected. Co-mutations of tumor protein p53 (TP53) and RB transcriptional corepressor $1(R B 1)$ were detected in $15.4 \%$ $(2 / 13), 42.1 \%(8 / 19)$, and $92.9 \%(13 / 14)$ of carcinoid tumors, LCNECs, and SCLCs, respectively. Oncogenic or targetable genetic alterations identified in this study included mutations of KRAS proto-oncogene (KRAS), phosphatidylinositol-4,5-bisphosphate 3-kinase catalytic subunit alpha (PIK3CA), ALK receptor tyrosine kinase $(A L K)$, mitogen-activated protein kinase kinase 1 $(M A P 2 K 1)$, and isocitrate dehydrogenase $1(I D H 1)$, as well as amplifications of erb-b2 receptor tyrosine kinase 2 $(E R B B 2)$, fibroblast growth factor receptor 1 (FGFR1), CD274 molecule (CD274), and MYCN proto-oncogene $(M Y C N)$. These alterations were more frequently found in high-grade NETs than in carcinoid tumors (33.3\% vs. $7.7 \%)$.
Genetic alterations in TCs and ACs. In TCs, TP53 (2/7, $28.6 \%)$ and $R B 1(2 / 7,28.6 \%)$ were rarely identified. TP53 and $R B 1$ co-mutation was detected in only one case, and pathological review confirmed the TC diagnosis. The Ki-67 labeling index for this case was less than $2 \%$. Interestingly, this case showed lymph node metastasis at the time of diagnosis. However, there was no recurrence over an 8-year follow-up period after surgical resection.

In ACs, mutations of TP53, RB1, and phosphatase and tensin homolog $(P T E N)$ were simultaneously found in one case. During follow-up, the patient with this tumor died due to another cancer (advanced renal cell carcinoma). Among the targetable oncogenes, a PIK3CA (p.H1047L) mutation was observed in one case $(1 / 6,16.7 \%)$.

Genetic alterations in LCNECs. TP53 (16/19, 84.2\%), RB1 (9/19, 42.3\%), PTEN (3/19, 15.8\%), and SWI/SNF related, matrix associated, actin dependent regulator of chromatin, subfamily a, member 4 (SMARCA4) $(2 / 19,10.5 \%)$ were identified in LCNECs. All mutations in the TP53 gene affected a critical functional DNA-binding domain. The majority of $R B 1$ mutations (88.9\%) were nonsense or frameshift variants. No serine/threonine kinase 11 (STK11) mutations were identified. Amplifications of ERBB2, MYCN, FGFR1, and $C D 274$ were each detected in one case $(1 / 19$, $5.3 \%)$. Expression and gene amplification of ERBB2 were 
A

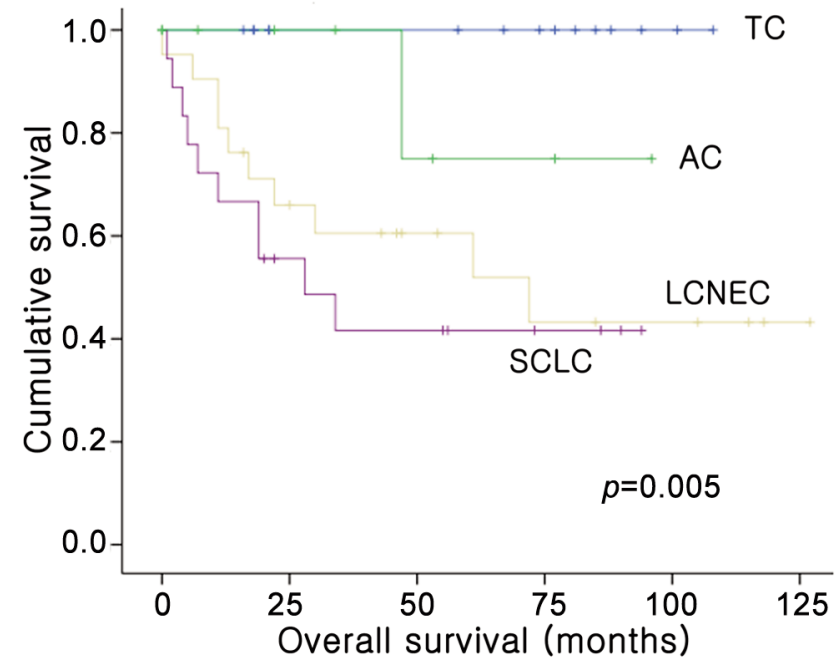

B

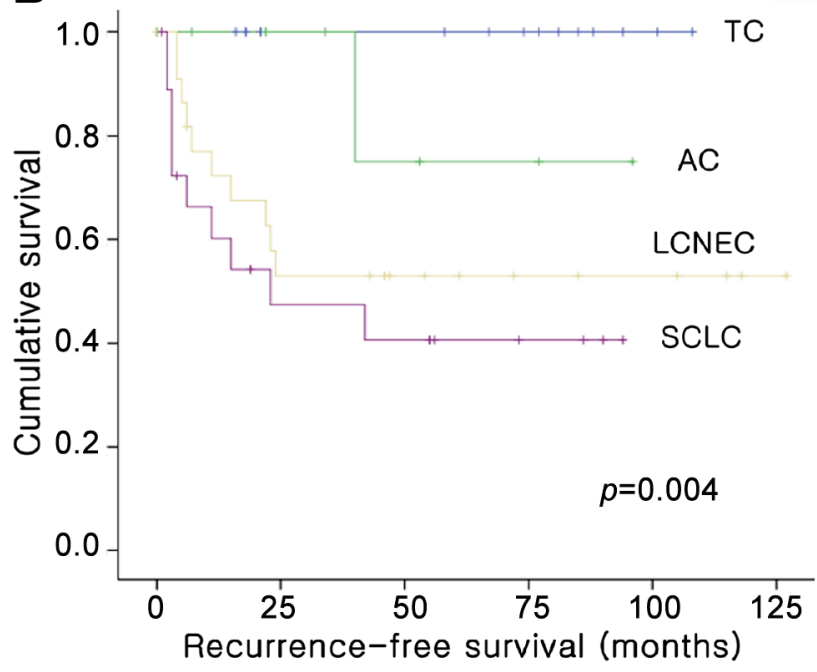

Figure 2. Survival curves according to the lung neuroendocrine tumor subtype. A: overall survival ( $p=0.005$ ), B: recurrence-free survival ( $p=0.004$ ).

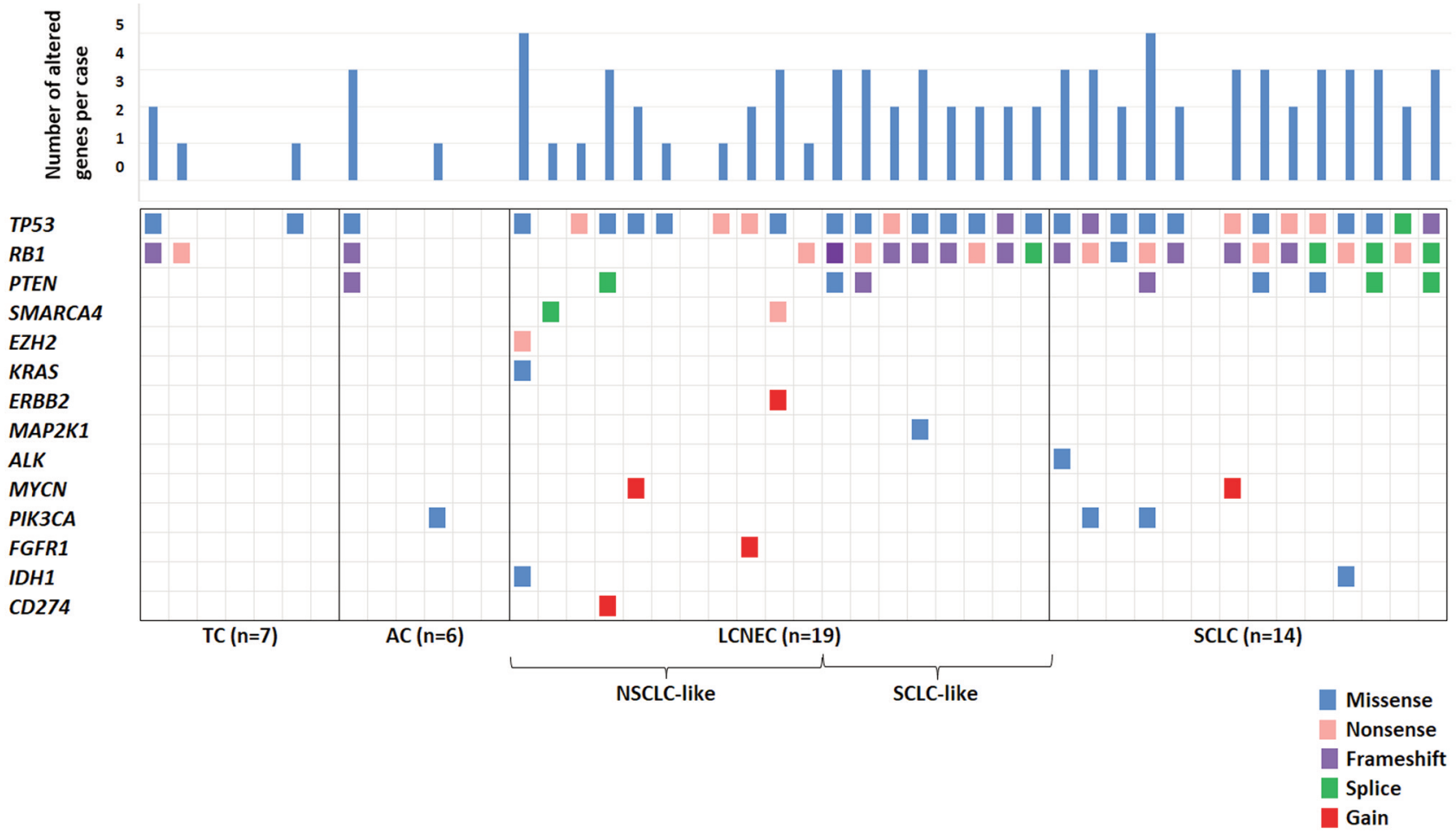

Figure 3. OncoPrint heatmap for genetic alterations in lung neuroendocrine tumors according to subtype. Please refer to Table I for gene designations. AC: Atypical carcinoid tumor; LCNEC: large-cell neuroendocrine carcinoma; SCLC: small-cell lung carcinoma; TC: typical carcinoid tumor.

confirmed by IHC and silver in situ hybridization, respectively (Figure $4 \mathrm{~A}$ and $\mathrm{B}$ ). We then categorized LCNECs into 'NSCLC-like' or 'SCLC-like' subtypes according to the TP53 and RBI co-mutation status, which is a defining event in SCLC. Notably, all the oncogenic alterations, including mutations of $K R A S$ (p.G12V) and IDH1 (p.R132C) and amplifications of ERBB2, MYCN, $F G F R 1$, and $C D 274$, were found in the 'NSCLC-like' 
Table III. Incidence of frequent (more than 1) genetic alterations in lung neuroendocrine tumors and their distributions according to the tumor subtype.

\begin{tabular}{|c|c|c|c|c|c|c|}
\hline Gene & All $(n=46)$ & $\mathrm{TC}(\mathrm{n}=7)$ & $\mathrm{AC}(\mathrm{n}=6)$ & $\operatorname{LCNEC~}(\mathrm{n}=19)$ & $\operatorname{SCLC}(n=14)$ & $p$-Value \\
\hline TP53 & & & & & & $<0.001$ \\
\hline Mutation & $32(69.6 \%)$ & $2(28.6 \%)$ & $1(16.7 \%)$ & $16(84.2 \%)$ & $13(92.9 \%)$ & \\
\hline Wild-type & $14(30.4 \%)$ & $5(71.4 \%)$ & $5(83.3 \%)$ & $3(15.8 \%)$ & $1(7.1 \%)$ & \\
\hline RB1 & & & & & & 0.003 \\
\hline Mutation & $25(54.3 \%)$ & $2(28.6 \%)$ & $1(16.7 \%)$ & $9(47.4 \%)$ & $13(92.9 \%)$ & \\
\hline Wild-type & $21(45.7 \%)$ & $5(71.4 \%)$ & $5(83.3 \%)$ & $10(52.6 \%)$ & $1(7.1 \%)$ & \\
\hline TP53+RB1 & & & & & & 0.001 \\
\hline Co-mutation & $23(50.0 \%)$ & $1(14.3 \%)$ & $1(16.7 \%)$ & $8(42.1 \%)$ & $13(92.9 \%)$ & \\
\hline Wild-type & $23(50.0 \%)$ & $6(85.7 \%)$ & $5(83.3 \%)$ & $11(57.9 \%)$ & $1(7.1 \%)$ & \\
\hline PTEN & & & & & & 0.238 \\
\hline Mutation & $9(19.6 \%)$ & $0(0.0 \%)$ & $1(16.7 \%)$ & $3(15.8 \%)$ & $5(35.7 \%)$ & \\
\hline Wild-type & $37(80.4 \%)$ & $7(100.0 \%)$ & $5(83.3 \%)$ & $16(84.2 \%)$ & $9(64.3 \%)$ & \\
\hline SMARCA4 & & & & & & 0.396 \\
\hline Mutation & $2(4.3 \%)$ & $0(0.0 \%)$ & $0(0.0 \%)$ & $2(10.5 \%)$ & $0(0.0 \%)$ & \\
\hline Wild-type & $44(95.7 \%)$ & $7(100.0 \%)$ & $6(100.0 \%)$ & $17(89.5 \%)$ & $14(100.0 \%)$ & \\
\hline IDH1 & & & & & & 0.827 \\
\hline Mutation & $2(4.3 \%)$ & $0(0.0 \%)$ & $0(0.0 \%)$ & $1(5.3 \%)$ & $1(7.1 \%)$ & \\
\hline Wild-type & $44(95.7 \%)$ & $7(100.0 \%)$ & $6(100.0 \%)$ & $18(94.7 \%)$ & $13(92.9 \%)$ & \\
\hline PIK3CA & & & & & & 0.189 \\
\hline Mutation & $3(6.5 \%)$ & $0(0.0 \%)$ & $1(16.7 \%)$ & $0(0.0 \%)$ & $2(14.3 \%)$ & \\
\hline Wild-type & $44(93.5 \%)$ & $7(100.0 \%)$ & $5(83.3 \%)$ & $19(100.0 \%)$ & $12(85.7 \%)$ & \\
\hline $\mathrm{MYCN}$ & & & & & & 0.827 \\
\hline Amplification & $2(4.3 \%)$ & $0(0.0 \%)$ & $0(0.0 \%)$ & $1(5.3 \%)$ & $1(7.1 \%)$ & \\
\hline No amplification & $44(95.7 \%)$ & $7(100.0 \%)$ & $6(100.0 \%)$ & $18(94.7 \%)$ & $13(92.9 \%)$ & \\
\hline
\end{tabular}

AC: Atypical carcinoid tumor; LCNEC: large-cell neuroendocrine carcinoma; SCLC: small-cell lung carcinoma; TC: typical carcinoid tumor. Please refer to Table I for gene designations.

subgroup, except for one case of 'SCLC-like' LCNEC with a $M A P 2 K 1$ (p.K57N) mutation. However, there were no statistically significant differences in clinicopathological parameters between the 'NSCLC-like' and 'SCLC-like' subtypes. In addition, OS did not demonstrate a statistically significant difference (Figure 5).

Genetic alterations in SCLCs. Mutations of TP53 (13/14, 92.8\%), RBI (13/14, 92.8\%), and PTEN (5/14, 35.7\%) were frequently identified in SCLCs. MYCN amplification was observed in one case $(1 / 14,7.1 \%)$. Co-mutation of TP53 and $R B 1$ was found in all cases except one $(13 / 14,92.8 \%)$. A pathological review of the case harboring neither TP53 nor RB1 mutations confirmed the diagnosis of SCLC. The Ki-67 labeling index for this case was approximately $80 \%$. Among oncogenic alterations, two PIK3CA mutations (p.E545K and p.G1049R), one $A L K$ mutation (p.R1275Q), and one IDHI mutation (p.R132H) were identified.

Association of PD-L1 status with NETs. PD-L1 22C3 IHC was performed on samples from 64 NET cases (Table IV). PD-L1 positivity was more frequently observed in LCNECs than in the other NET subtypes $(p=0.002)$. A case of LCNEC with CD274 amplification showed TPS of $100 \%$ in PD-L1
IHC (Figure 4C). Upon further categorization of LCNECs into 'NSCLC-like' and 'SCLC-like' subtypes, there was no statistically significant difference in PD-L1 expression but 'NSCLC-like' LCNECs tended to display higher expression levels of PD-L1.

\section{Discussion}

In this study, we demonstrated that the mutational status of TP53 and RB1 is important for NET categorization in East Asian patients. There may also be opportunities for targeted therapy or immunotherapy in patients with NETs despite inter-tumor heterogeneity.

In this study, the frequency of TP53 or RB1 mutation was low in TCs and ACs, compared to that in high-grade NETs. One TC case harbored the co-mutation of TP53 and RBI and showed lymph node metastasis at the time of diagnosis. However, there was no recurrence after complete surgical resection. More clinical case studies are needed to investigate the clinical significance of morphologically carcinoid tumors with co-mutations of TP53 and RB1. The frequency of targetable genetic alterations was also very low in TCs and ACs. Previous studies observed frequent mutations in chromatin-remodeling genes and the menin 1 

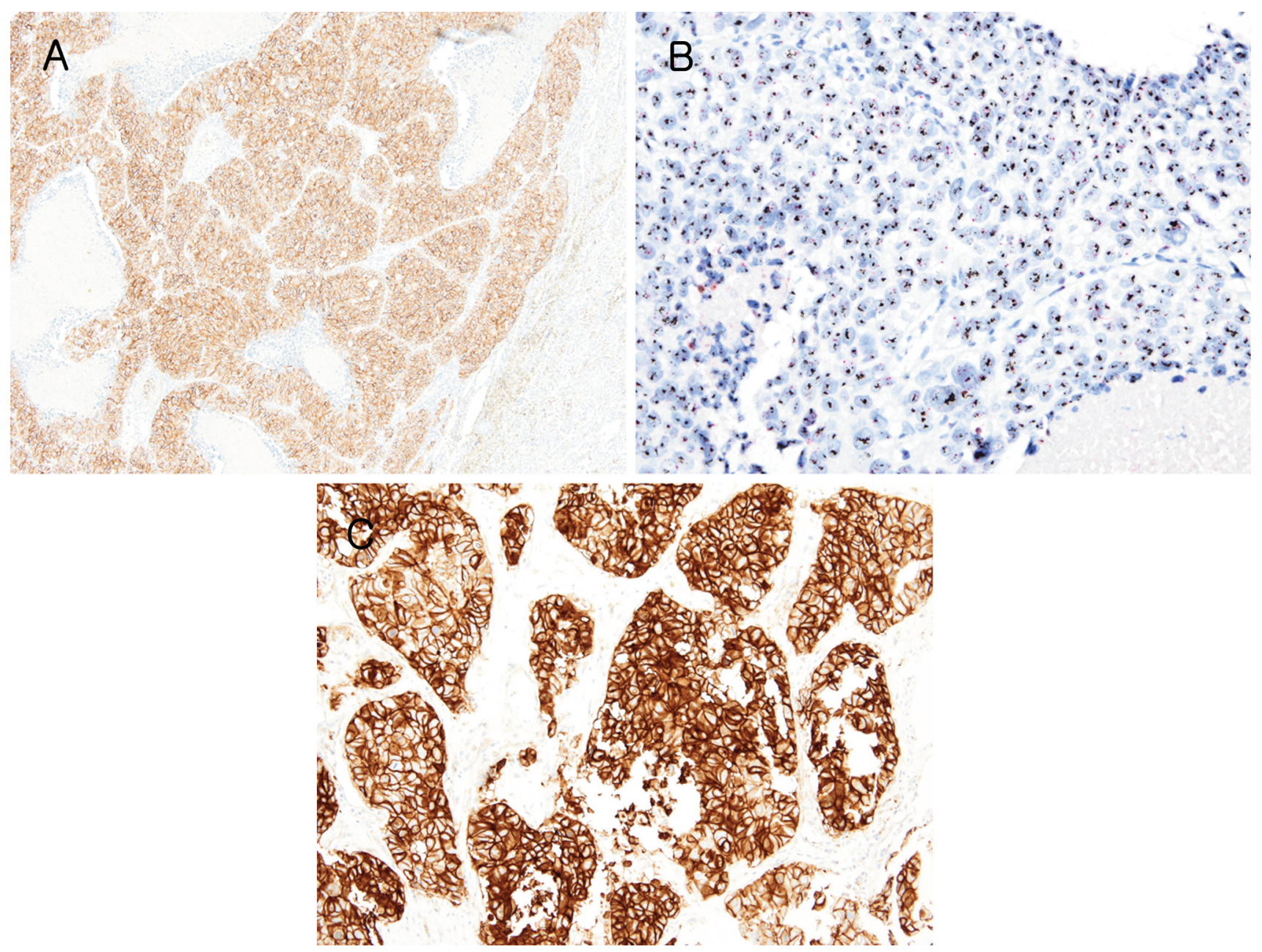

Figure 4. A case of large-cell neuroendocrine carcinoma (LCNEC) harboring amplifications of erb-b2 receptor tyrosine kinase 2 (ERBB2 or HER2) ( $A$ and $B)$ and CD274 (C). A: HER2 immunohistochemical staining demonstrates diffuse membranous positivity. B: ERBB2 silver in-situ hybridization illustrates the amplification of the ERBB2 gene. C: A case of LCNEC with a CD274 amplification with a 100\% tumor proportion score in programmed cell death-ligand 1 (PD-L1) immunohistochemical staining.

(MEN1) gene $(6,10)$. The NGS gene panel used in this study was mainly designed for targetable genetic alterations in lung cancer; hence, we were unable to examine the frequency of mutations in the MEN1 gene or chromatin-remodeling genes.

In this study, we also demonstrated that the co-mutational status of TP53 and RBI can divide LCNECs into two subgroups. There was a clear distinction in terms of genetic alterations between 'NSCLC-like' and 'SCLC-like' LCNECs, which was consistent with previous studies $(5,8)$. Rekhtman et al. characterized 'SCLC-like' LCNECs as having a TP53 and $R B 1$ co-mutation and 'NSCLC-like' LCNECs as lacking a TP53 and $R B 1$ co-mutation, but retaining the presence of an NSCLC mutation, such as STK11, KRAS, and kelch like ECH associated protein 1 (KEAPl) (8). In our study, a KRAS mutation was identified in only one case of 'NSCLC-like' LCNEC, and no STK mutations were detected. This is likely due to ethnicity-related variations in frequently altered genes. With regard to NSCLCs, previous studies have consistently reported lower rates of KRAS and STK11 mutations in East Asian populations than in Western populations $(17,25,26)$. This trend was also reported in a Japanese cohort of LCNECs (7). In LCNEC cases among Western populations, the frequency of KRAS mutations was $22 \%$ but in a Japanese cohort it was only $6 \%(7,8)$.

For SCLCs, all cases except one harbored a TP53 and RBI co-mutation, which is a key event in SCLC tumorigenesis. In addition, oncogenic mutations in PIK3CA, $I D H 1$, and $A L K$ were observed. Recent studies have indicated that SCLCs may consist of a heterogeneous subset, contradicting the traditional concept that SCLCs share a homogenous nature $(11,27,28)$. SCLCs can be categorized depending on the expression of achaete-scute family bHLH 
in vivo $34: 3375-3385(2020)$

Table IV. Programmed cell death-ligand 1 (PD-L1) expression according to the lung neuroendocrine tumor subtype.

\begin{tabular}{|c|c|c|c|c|c|}
\hline & All $(n=64)$ & Carcinoid tumor $(\mathrm{n}=24)$ & $\operatorname{LCNEC~}(\mathrm{n}=21)$ & $\operatorname{SCLC}(n=19)$ & $p$-Value \\
\hline PD-L1 TPS & $8.7 \pm 22.9 \%$ & $4.3 \pm 15.3 \%$ & $20.6 \pm 34.1 \%$ & $1.2 \pm 3.5 \%$ & 0.037 \\
\hline PD-L1 & & & & & 0.001 \\
\hline Positive* & $21(32.8 \%)$ & $3(12.5 \%)$ & $13(61.9 \%)$ & $5(26.3 \%)$ & \\
\hline Negative & $43(67.2 \%)$ & $21(87.5 \%)$ & $8(38.1 \%)$ & $14(73.7 \%)$ & \\
\hline
\end{tabular}

LCNEC: Large-cell neuroendocrine carcinoma; SCLC: small-cell lung carcinoma; TPS: tumor proportion score. *PD-L1 positivity was defined as TPS $\geq 1 \%$.

transcription factor 1 (ASCL1), neuronal differentiation 1 (NeuroD1), Yes1 associated transcriptional regulator $(Y A P 1)$, or POU class 2 homeobox 3 (POU2F3) $(27,28)$. Because we performed targeted NGS only, we were unable to correlate the genomic data with expression changes in ASCL1, NeuroD1, YAP1, or POU2F3. Further studies are necessary to investigate the clinical significance of the molecular subtypes of SCLC based on the transcriptional expression profiles. In this study, PTEN mutations were detected in five out of 14 SCLCs (36\%). PTEN was suggested to be a potent suppressor of SCLC (29). The PIK3CA/PTEN pathway was altered in $43 \%$ of SCLCs in our cohort. This finding may implicate the PIK3 pathway inhibitors as a targeted therapy for a subset of patients with SCLC.

In terms of therapeutic potential, the detection of targetable mutations in high-grade NETs supports the necessity of NGS testing to identify the drug target, despite the relatively low frequency of these mutations. Since current treatment of unresectable NETs is largely based on platinum-based chemotherapy, detection of these genetic alterations might benefit patients by providing a novel therapeutic option $(30,31)$.

Cancer immunotherapy using immune checkpoint inhibitors (ICIs) has become a standard of care in the treatment of patients with lung cancer. IHC for PD-L1 is used as a predictive marker for response to ICIs (32). In this study, PDL1 positivity was significantly related to high-grade NETs, especially LCNECs. This finding is consistent with previous studies (18-20). Kim et al. reported that the PD-1/PD-L1 pathway was activated in high-grade neuroendocrine carcinoma and may be related to higher mutational burdens (18). George et al. found that the expression of the components of immunerelated pathways was increased in a subset of LCNECs, based on transcriptomic analysis (5). Given these findings, including those of our study, immunotherapy may serve as a treatment option for high-grade NETs, as previously described by the clinical response to ICIs $(33,34)$.

This study has several limitations. Since we applied an NGS panel that was mainly included well-known oncogene or tumor-suppressor genes, more recently described important genes in lung NETs were not included, such as

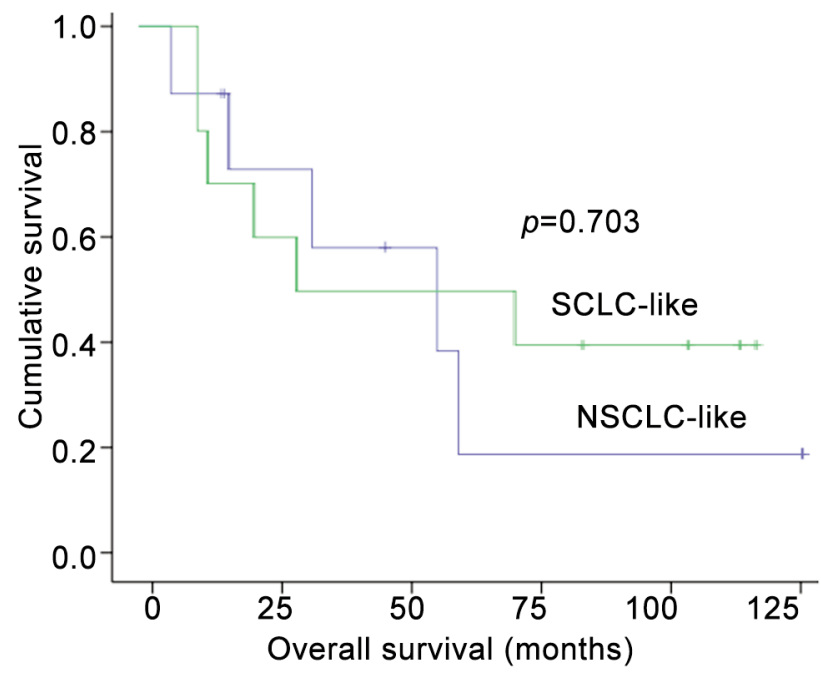

Figure 5. Overall survival according to the large-cell neuroendocrine carcinoma molecular subtype $(p=0.703)$.

members of the NOTCH family, KEAP1, or MEN1. Limited sample numbers may also have affected the frequency of well-known driver mutations in lung NETs. Thus, subsequent large-scale studies are needed to confirm the genetic and clinicopathologic findings addressed in previous researches and the current work through the application of more detailed genomic analyses.

In conclusion, the mutational status of TP53 and RBI was associated with NET subtypes, implying associations with tumorigenesis, biological behavior, and targetable genetic alterations. Although the frequency of such targetable alterations is found to be low, an NGS panel test is recommended because they were detected in high-grade NETs. In addition to these targetable mutations, our study also suggests that immunotherapy represents a viable treatment option for a subset of high-grade NETs.

\section{Conflicts of Interest}

The Authors declare no conflicts of interest. 


\section{Authors' Contributions}

HSS and MK designed the study and wrote the initial draft of the article. All Authors contributed to data collection and interpretation, and critically reviewed the article. All Authors read and approved the final manuscript.

\section{Acknowledgements}

This research was supported by the Basic Science Research Program through the National Research Foundation of Korea (NRF) funded by the Ministry of Education (NRF-2018R1D1A1B 07047811). We would like to thank Editage (www.editage.co.kr) for English language editing.

\section{References}

1 Travis WD, Brambilla E, Nicholson AG, Yatabe Y, Austin JHM, Beasley MB, Chirieac LR, Dacic S, Duhig E, Flieder DB, Geisinger K, Hirsch FR, Ishikawa Y, Kerr KM, Noguchi M, Pelosi G, Powell CA, Tsao MS, Wistuba I and Panel WHO: The 2015 world health organization classification of lung tumors: Impact of genetic, clinical and radiologic advances since the 2004 classification. J Thorac Oncol 10(9): 1243-1260, 2015. PMID: 26291008. DOI: 10.1097/JTO.0000000000000630

2 Rindi G, Klimstra DS, Abedi-Ardekani B, Asa SL, Bosman FT, Brambilla E, Busam KJ, de Krijger RR, Dietel M, El-Naggar AK, Fernandez-Cuesta L, Kloppel G, McCluggage WG, Moch H, Ohgaki H, Rakha EA, Reed NS, Rous BA, Sasano H, Scarpa A, Scoazec JY, Travis WD, Tallini G, Trouillas J, van Krieken JH and Cree IA: A common classification framework for neuroendocrine neoplasms: An international agency for research on cancer (iarc) and world health organization (who) expert consensus proposal. Mod Pathol 31(12): 1770-1786, 2018. PMID: 30140036. DOI: 10.1038/s41379-018-0110-y

3 Hendifar AE, Marchevsky AM and Tuli R: Neuroendocrine tumors of the lung: Current challenges and advances in the diagnosis and management of well-differentiated disease. J Thorac Oncol 12(3): 425-436, 2017. PMID: 27890494. DOI: 10.1016/j.jtho.2016.11.2222

4 Alcala N, Leblay N, Gabriel AAG, Mangiante L, Hervas D, Giffon T, Sertier AS, Ferrari A, Derks J, Ghantous A, Delhomme TM, Chabrier A, Cuenin C, Abedi-Ardekani B, Boland A, Olaso R, Meyer V, Altmuller J, Le Calvez-Kelm F, Durand G, Voegele C, Boyault S, Moonen L, Lemaitre N, Lorimier P, Toffart AC, Soltermann A, Clement JH, Saenger J, Field JK, Brevet M, Blanc-Fournier C, Galateau-Salle F, Le Stang N, Russell PA, Wright G, Sozzi G, Pastorino U, Lacomme S, Vignaud JM, Hofman V, Hofman P, Brustugun OT, Lund-Iversen M, Thomas de Montpreville V, Muscarella LA, Graziano P, Popper H, Stojsic J, Deleuze JF, Herceg Z, Viari A, Nuernberg P, Pelosi G, Dingemans AMC, Milione M, Roz L, Brcic L, Volante M, Papotti MG, Caux C, Sandoval J, Hernandez-Vargas H, Brambilla E, Speel EJM, Girard N, Lantuejoul S, McKay JD, Foll M and Fernandez-Cuesta L: Integrative and comparative genomic analyses identify clinically relevant pulmonary carcinoid groups and unveil the supra-carcinoids. Nat Commun 10(1): 3407, 2019. PMID: 31431620. DOI: $10.1038 / \mathrm{s} 41467-019-11276-9$
5 George J, Walter V, Peifer M, Alexandrov LB, Seidel D, Leenders F, Maas L, Muller C, Dahmen I, Delhomme TM, Ardin M, Leblay N, Byrnes G, Sun R, De Reynies A, McLeer-Florin A, Bosco G, Malchers F, Menon R, Altmuller J, Becker C, Nurnberg P, Achter V, Lang U, Schneider PM, Bogus M, Soloway MG, Wilkerson MD, Cun Y, McKay JD, Moro-Sibilot D, Brambilla CG, Lantuejoul S, Lemaitre N, Soltermann A, Weder W, Tischler V, Brustugun OT, Lund-Iversen M, Helland A, Solberg S, Ansen S, Wright G, Solomon B, Roz L, Pastorino U, Petersen I, Clement JH, Sanger J, Wolf J, Vingron M, Zander T, Perner S, Travis WD, Haas SA, Olivier M, Foll M, Buttner R, Hayes DN, Brambilla E, Fernandez-Cuesta L and Thomas RK: Integrative genomic profiling of large-cell neuroendocrine carcinomas reveals distinct subtypes of high-grade neuroendocrine lung tumors. Nat Commun 9(1): 1048, 2018. PMID: 29535388. DOI: 10.1038/s41467-018-03099-x

6 Simbolo M, Mafficini A, Sikora KO, Fassan M, Barbi S, Corbo V, Mastracci L, Rusev B, Grillo F, Vicentini C, Ferrara R, Pilotto S, Davini F, Pelosi G, Lawlor RT, Chilosi M, Tortora G, Bria E, Fontanini G, Volante M and Scarpa A: Lung neuroendocrine tumours: Deep sequencing of the four world health organization histotypes reveals chromatin-remodelling genes as major players and a prognostic role for tert, rb1, men1 and kmt2d. J Pathol 241(4): 488-500, 2017. PMID: 27873319. DOI: 10.1002/ path. 4853

7 Miyoshi T, Umemura S, Matsumura Y, Mimaki S, Tada S, Makinoshima H, Ishii G, Udagawa H, Matsumoto S, Yoh K, Niho S, Ohmatsu H, Aokage K, Hishida T, Yoshida J, Nagai K, Goto K, Tsuboi M and Tsuchihara K: Genomic profiling of large-cell neuroendocrine carcinoma of the lung. Clin Cancer Res 23(3): 757-765, 2017. PMID: 27507618. DOI: 10.1158/ 1078-0432.CCR-16-0355

8 Rekhtman N, Pietanza MC, Hellmann MD, Naidoo J, Arora A, Won H, Halpenny DF, Wang H, Tian SK, Litvak AM, Paik PK, Drilon AE, Socci N, Poirier JT, Shen R, Berger MF, Moreira AL, Travis WD, Rudin CM and Ladanyi M: Next-generation sequencing of pulmonary large cell neuroendocrine carcinoma reveals small cell carcinoma-like and non-small cell carcinomalike subsets. Clin Cancer Res 22(14): 3618-3629, 2016. PMID: 26960398. DOI: 10.1158/1078-0432.CCR-15-2946

9 George J, Lim JS, Jang SJ, Cun Y, Ozretic L, Kong G, Leenders F, Lu X, Fernandez-Cuesta L, Bosco G, Muller C, Dahmen I, Jahchan NS, Park KS, Yang D, Karnezis AN, Vaka D, Torres A, Wang MS, Korbel JO, Menon R, Chun SM, Kim D, Wilkerson M, Hayes N, Engelmann D, Putzer B, Bos M, Michels S, Vlasic I, Seidel D, Pinther B, Schaub P, Becker C, Altmuller J, Yokota J, Kohno T, Iwakawa R, Tsuta K, Noguchi M, Muley T, Hoffmann H, Schnabel PA, Petersen I, Chen Y, Soltermann A, Tischler V, Choi CM, Kim YH, Massion PP, Zou Y, Jovanovic D, Kontic M, Wright GM, Russell PA, Solomon B, Koch I, Lindner M, Muscarella LA, la Torre A, Field JK, Jakopovic M, Knezevic J, Castanos-Velez E, Roz L, Pastorino U, Brustugun OT, Lund-Iversen M, Thunnissen E, Kohler J, Schuler M, Botling J, Sandelin M, Sanchez-Cespedes M, Salvesen HB, Achter V, Lang U, Bogus M, Schneider PM, Zander T, Ansen S, Hallek M, Wolf J, Vingron M, Yatabe Y, Travis WD, Nurnberg P, Reinhardt C, Perner S, Heukamp L, Buttner R, Haas SA, Brambilla E, Peifer M, Sage J and Thomas RK: Comprehensive genomic profiles of small cell lung cancer. Nature 524(7563): 47-53, 2015. PMID: 26168399. DOI: 10.1038/nature14664 
10 Fernandez-Cuesta L, Peifer M, Lu X, Sun R, Ozretic L, Seidal D, Zander T, Leenders F, George J, Muller C, Dahmen I, Pinther B, Bosco G, Konrad K, Altmuller J, Nurnberg P, Achter V, Lang U, Schneider PM, Bogus M, Soltermann A, Brustugun OT, Helland A, Solberg S, Lund-Iversen M, Ansen S, Stoelben E, Wright GM, Russell P, Wainer Z, Solomon B, Field JK, Hyde R, Davies MP, Heukamp LC, Petersen I, Perner S, Lovly C, Cappuzzo F, Travis WD, Wolf J, Vingron M, Brambilla E, Haas SA, Buettner R and Thomas RK: Frequent mutations in chromatin-remodelling genes in pulmonary carcinoids. Nat Commun 5: 3518, 2014. PMID: 24670920. DOI: $10.1038 /$ ncomms4518

11 Yang D, Denny SK, Greenside PG, Chaikovsky AC, Brady JJ, Ouadah Y, Granja JM, Jahchan NS, Lim JS, Kwok S, Kong CS, Berghoff AS, Schmitt A, Reinhardt HC, Park KS, Preusser M, Kundaje A, Greenleaf WJ, Sage J and Winslow MM: Intertumoral heterogeneity in sclc is influenced by the cell type of origin. Cancer Discov 8(10): 1316-1331, 2018. PMID: 30228179. DOI: $10.1158 / 2159-8290 . C D-17-0987$

12 Gazdar AF: Morphologic and other forms of heterogeneity in small cell lung cancer: What can we learn from them? J Thorac Oncol 13(2): 148-150, 2018. PMID: 29425612. DOI: 10.1016/ j.jtho.2017.11.004

13 Zhang W, Girard L, Zhang YA, Haruki T, Papari-Zareei M, Stastny V, Ghayee HK, Pacak K, Oliver TG, Minna JD and Gazdar AF: Small cell lung cancer tumors and preclinical models display heterogeneity of neuroendocrine phenotypes. Transl Lung Cancer Res 7(1): 32-49, 2018. PMID: 29535911. DOI: $10.21037 /$ tlcr.2018.02.02

14 Horie M, Miyashita N, Mattsson JSM, Mikami Y, Sandelin M, Brunnstrom H, Micke P, Nagase T and Saito A: An integrative transcriptome analysis reveals a functional role for thyroid transcription factor-1 in small cell lung cancer. J Pathol 246(2): 154-165, 2018. PMID: 29876935. DOI: 10.1002/path.5109

15 Zhuo M, Guan Y, Yang X, Hong L, Wang Y, Li Z, Chen R, Abbas HA, Chang L, Gong Y, Wu N, Zhong J, Chen W, Chen H, Dong Z, Zhu X, Li J, Wang Y, An T, Wu M, Wang Z, Wang J, Roarty EB, Rinsurongkawong W, Lewis J, Roth JA, Swisher SG, Lee JJ, Heymach JV, Wistuba, II, Kalhor N, Yang L, Yi X, Futreal PA, Glisson BS, Xia X, Zhang J and Zhao J: The prognostic and therapeutic role of genomic subtyping by sequencing tumor or cell-free DNA in pulmonary large-cell neuroendocrine carcinoma. Clin Cancer Res 26(4): 892-901, 2020. PMID: 31694833. DOI: 10.1158/1078-0432.Ccr-19-0556

16 Simbolo M, Barbi S, Fassan M, Mafficini A, Ali G, Vicentini C, Sperandio N, Corbo V, Rusev B, Mastracci L, Grillo F, Pilotto S, Pelosi G, Pelliccioni S, Lawlor RT, Tortora G, Fontanini G, Volante M, Scarpa A and Bria E: Gene expression profiling of lung atypical carcinoids and large cell neuroendocrine carcinomas identifies three transcriptomic subtypes with specific genomic alterations. J Thorac Oncol 14(9): 1651-1661, 2019. PMID: 31085341. DOI: 10.1016/j.jtho.2019.05.003

17 Chun YJ, Choi JW, Hong MH, Jung D, Son H, Cho EK, Min YJ, Kim SW, Park K, Lee SS, Kim S, Kim HR, Cho BC and Korean Lung Cancer C: Molecular characterization of lung adenocarcinoma from korean patients using next generation sequencing. PLoS One 14(11): e0224379, 2019. PMID: 31765373. DOI: 10.1371/journal.pone.0224379

18 Kim HS, Lee JH, Nam SJ, Ock CY, Moon JW, Yoo CW, Lee GK and Han JY: Association of pd-11 expression with tumorinfiltrating immune cells and mutation burden in high-grade neuroendocrine carcinoma of the lung. J Thorac Oncol 13(5): 636648, 2018. PMID: 29378266. DOI: 10.1016/j.jtho.2018.01.008

19 Tsuruoka K, Horinouchi H, Goto Y, Kanda S, Fujiwara Y, Nokihara H, Yamamoto N, Asakura K, Nakagawa K, Sakurai H, Watanabe SI, Tsuta $\mathrm{K}$ and Ohe Y: Pd-11 expression in neuroendocrine tumors of the lung. Lung Cancer 108: 115-120, 2017. PMID: 28625622. DOI: 10.1016/j.lungcan.2017.03.006

20 Eichhorn F, Harms A, Warth A, Muley T, Winter H and Eichhorn ME: Pd-11 expression in large cell neuroendocrine carcinoma of the lung. Lung Cancer 118: 76-82, 2018. PMID: 29572007. DOI: $10.1016 /$ j.lungcan.2018.02.003

21 Ohtaki Y, Kaira K, Atsumi J, Nagashima T, Kawashima O, Ibe T, Kamiyoshihara M, Onozato R, Fujita A, Yazawa T, Sugano M, Iijima M, Nakazawa S, Obayashi K, Kosaka T, Yajima T, Kuwano H, Shirabe K, Mogi A and Shimizu K: Prognostic significance of pd-11 expression and tumor infiltrating lymphocytes in large cell neuroendocrine carcinoma of lung. Am J Transl Res 10(10): 3243-3253, 2018. PMID: 30416665.

22 Hermans BCM, Derks JL, Thunnissen E, van Suylen RJ, den Bakker MA, Groen HJM, Smit EF, Damhuis RA, van den Broek EC, Stallinga CM, Roemen GM, Speel EJM and Dingemans AC: Prevalence and prognostic value of pd-11 expression in molecular subtypes of metastatic large cell neuroendocrine carcinoma (lcnec). Lung Cancer 130: 179-186, 2019. PMID: 30885341. DOI: 10.1016/j.lungcan.2019.02.022

23 Rami-Porta R, Asamura H, Travis WD and Rusch VW: Lung cancer - major changes in the american joint committee on cancer eighth edition cancer staging manual. CA Cancer J Clin 67(2): 138-155, 2017. PMID: 28140453. DOI: 10.3322/caac. 21390

24 Li MM, Datto M, Duncavage EJ, Kulkarni S, Lindeman NI, Roy S, Tsimberidou AM, Vnencak-Jones CL, Wolff DJ, Younes A and Nikiforova MN: Standards and guidelines for the interpretation and reporting of sequence variants in cancer: A joint consensus recommendation of the association for molecular pathology, american society of clinical oncology, and college of american pathologists. J Mol Diagn 19(1): 4-23, 2017. PMID: 27993330. DOI: 10.1016/j.jmoldx.2016.10.002

25 Yang S, Yu X, Fan Y, Shi X and Jin Y: Clinicopathologic characteristics and survival outcome in patients with advanced lung adenocarcinoma and kras mutation. J Cancer 9(16): 29302937, 2018. PMID: 30123361. DOI: 10.7150/jca.24425

26 Zhang XC, Wang J, Shao GG, Wang Q, Qu X, Wang B, Moy C, Fan Y, Albertyn Z, Huang X, Zhang J, Qiu Y, Platero S, Lorenzi MV, Zudaire E, Yang J, Cheng Y, Xu L and Wu YL: Comprehensive genomic and immunological characterization of chinese non-small cell lung cancer patients. Nat Commun 10(1): 1772, 2019. PMID: 30992440. DOI: 10.1038/s41467-01909762-1

27 Huang Y-H, Klingbeil O, He X-Y, Wu XS, Arun G, Lu B, Somerville TDD, Milazzo JP, Wilkinson JE, Demerdash OE, Spector DL, Egeblad M, Shi J and Vakoc CR: Pou2f3 is a master regulator of a tuft cell-like variant of small cell lung cancer. Genes Dev 32(13-14): 915-928, 2018. PMID: 29945888. DOI: $10.1101 / \mathrm{gad} .314815 .118$

28 Rudin CM, Poirier JT, Byers LA, Dive C, Dowlati A, George J, Heymach JV, Johnson JE, Lehman JM, MacPherson D, Massion PP, Minna JD, Oliver TG, Quaranta V, Sage J, Thomas RK, Vakoc CR and Gazdar AF: Molecular subtypes of small cell lung cancer: A synthesis of human and mouse model data. Nat Rev 
Cancer 19(5): 289-297, 2019. PMID: 30926931. DOI: 10.1038/ s41568-019-0133-9

29 Cui M, Augert A, Rongione M, Conkrite K, Parazzoli S, Nikitin $\mathrm{AY}$, Ingolia N and MacPherson D: Pten is a potent suppressor of small cell lung cancer. Mol Cancer Res 12(5): 654-659, 2014. PMID: 24482365. DOI: 10.1158/1541-7786.Mcr-13-0554

30 Bunn PA, Jr., Minna JD, Augustyn A, Gazdar AF, Ouadah Y, Krasnow MA, Berns A, Brambilla E, Rekhtman N, Massion PP, Niederst M, Peifer M, Yokota J, Govindan R, Poirier JT, Byers LA, Wynes MW, McFadden DG, MacPherson D, Hann CL, Farago AF, Dive C, Teicher BA, Peacock CD, Johnson JE, Cobb MH, Wendel HG, Spigel D, Sage J, Yang P, Pietanza MC, Krug LM, Heymach J, Ujhazy P, Zhou C, Goto K, Dowlati A, Christensen CL, Park K, Einhorn LH, Edelman MJ, Giaccone G, Gerber DE, Salgia R, Owonikoko T, Malik S, Karachaliou N, Gandara DR, Slotman BJ, Blackhall F, Goss G, Thomas R, Rudin CM and Hirsch FR: Small cell lung cancer: Can recent advances in biology and molecular biology be translated into improved outcomes? J Thorac Oncol 11(4): 453-474, 2016. PMID: 26829312. DOI: 10.1016/j.jtho.2016.01.012

31 Ichiki Y, Matsumiya H, Mori M, Kanayama M, Nabe Y, Taira A, Shinohara S, Kuwata T, Takenaka M, Hirai A, Imanishi N, Yoneda K, Noguchi H, Shimajiri S, Fujino Y, Nakayama T and Tanaka F: Predictive factors of postoperative survival among patients with pulmonary neuroendocrine tumor. J Thorac Dis 10(12): 6912-6920, 2018. PMID: 30746237. DOI: $10.21037 /$ jtd.2018.11.115
32 Lantuejoul S, Sound-Tsao M, Cooper WA, Girard N, Hirsch FR, Roden AC, Lopez-Rios F, Jain D, Chou TY, Motoi N, Kerr KM, Yatabe Y, Brambilla E, Longshore J, Papotti M, Sholl LM, Thunnissen E, Rekhtman N, Borczuk A, Bubendorf L, Minami Y, Beasley MB, Botling J, Chen G, Chung JH, Dacic S, Hwang D, Lin D, Moreira A, Nicholson AG, Noguchi M, Pelosi G, Poleri C, Travis W, Yoshida A, Daigneault JB, Wistuba, II and Mino-Kenudson M: Pd-11 testing for lung cancer in 2019: Perspective from the iaslc pathology committee. J Thorac Oncol 15(4): 499-519, 2020. PMID: 31870882. DOI: 10.1016/j.jtho. 2019.12.107

33 Takimoto Sato M, Ikezawa Y, Sato M, Suzuki A and Kawai Y: Large cell neuroendocrine carcinoma of the lung that responded to nivolumab: A case report. Mol Clin Oncol 13(1): 43-47, 2020. PMID: 32499913. DOI: 10.3892/mco.2020.2045

34 Wang VE, Urisman A, Albacker L, Ali S, Miller V, Aggarwal R and Jablons D: Checkpoint inhibitor is active against large cell neuroendocrine carcinoma with high tumor mutation burden. J Immunother Cancer 5(1): 75, 2017. PMID: 28923100. DOI: 10.1186/s40425-017-0281-y
Received June 16, 2020

Revised July 17, 2020

Accepted July 21, 2020 